\title{
ESTIMATES OF DWPF CANISTER PRODUCTION (U)
}

by

M. J. Plodinec

$\therefore$

Westinghouse Savannah River Company

Savannah River Site

Aiken, South Carolina 29808

This report was prepared in connection with work done under Contract No. DE-AC09-89SR18035 with the U.S. Department of Energy. By acceptance of this report, the publisher and/or recipient acknowledges the U.S. Government's right to retain a nonexclusive, royalty-free license in and to any copyright covering this report, along with the right to reproduce and to authorize others to reproduce all or part of the copyrighted report. 


\section{DISCLAIMER}

This report was prepared as an account of work sponsored by an agency of the United States Government. Neither the United States Government nor any agency thereof, nor any of their employees, makes any warranty, express or implied, or assumes any legal liability or responsibility for the accuracy, completeness, or usefulness of any information, apparatus, product, or process disclosed, or represents that its use would not infringe privately owned rights. Reference hercin to any specific commercial product, process, or service by trade name, trademark, manufacturer, or otherwise does not necessarily constitute or imply its endorsement, recommendation, or favoring by the United States Government or any agency thereof. The views and opinions of authors expressed herein do not necessarily state or reflect those of the United States Government or any agency thereof.

This report has been reproduced direcly from the best available copy.

Available to DOE and DOE contractors from the Office of Scientific and Technical Information, P.O. Box 62, Oak Ridge, TN 37831; prices available from (615) 576-8401, FTS 626-8401.

Available to the public from the National Technical Information Service, U.S. Department of Commerce, 52855 Port Royal Rd., Springfield, VA 22161. 
TO: E. W. HOLTZSCHEITER

FROM: M. J. PLODINEC $t$ (स⿺

ESTIMATES OK DWEF CANISTEB_ERORUCTION

\section{INTRODUCTION AND SUMMARY}

Specification 1.2 of the repository program's Waste Accentance Preliminary Specifications (WAPS) 1 requires that the DWF estimate the radionuclide inventory, and provide the error of the estimate, for each waste type (assumed to be each sludge batch). The inventory of any radionuclide is directly proportional to the number of canisters produced from that sludge batch. Thus, estimating the number of canisters to be produced from each sludge batch is an important part of complying with this specification.

In this report, the number of canisters to be produced from each batch of sludge is estimated. This leads to the conclusion that approximately 5200 canisters will be produced by the DWPF through the year 2010. Thereafter, it is conservatively estimated that up to 124 canisters will be produced each year. The errors in these estimates are also discussed.

\section{BACKGROUND}

Specification 1.2 of the repository program's WAPS states
"The producer shall report the estimated inventory of radionuclides ... for each waste type ...
The producer shall provide in the WQR estimates of the total quantities of individual radjonuclides to be shipped to the repository and the estimated error in the values. The producer shall also provide in the WQR es- timates of the inventories for each waste type and the estimated error. ..."

As discussed in the Waste Form Compliance Plan, 2 the DWPF is defining each Tank Farm sludge batch to be a waste type for purposes of compliance with this specification. The inventory of each individual radionuclide can be calculated as the product of the concentration of that radionuclide per canister, and the number of canisters to be produced from that sludge batch. The purpose of this report is to provide estimates of the number of canisters to be produced from each sludge batch, and to estimate the error in those estimates. In addition, a tentative sludge processing schedule (based on a $12 / 93$ start of radioactive operations) is also provided. The estimates provided in this report may also be useful in determining the disposal fee for DWPF canisters. : 


\section{ASSUMRTIONS}

The number of canisters to be produced from a given sludge batch can be calculated on either a volumetric or a mass basis. The volumetric calculation is quite simple. The number of canisters produced from a given sludge batch is simply the sludge volume divided by 290,000 galions, times 410 canisters. This is derived from the DWPE design basis (conversion of 290,000 gallons per year: of sludge into 410 canisters of glass). ${ }^{3}$

The mass calculation is somewhat more complicated. The volume of sludge is converted to a mass basis by multiplying the pounds per gallon of sludge by the sludge volume. This mass is then converted to an oxide basis by multiplying the mass of sludge by a conversion factor to get mass of oxides (i.e., to get to a mass of sludge in glass basis). This mass is then divided by the expected mass of sludge oxides in each canister. Thus, for each sludge batch,

\section{Number of canisters $=$ (sludge batch volume) $x$ \\ (sludge solids per unit volume) $x$ (oxides per unit mass of sludge) / (mass of sludge in each canister)}

The sludge batches, and their associated volumes, are based on plans for processing the current waste inventory. ${ }^{4}$ These are based on processing the oldest wastes as soon as possible, on emptying the waste tanks as rapidly as possible, and on a moderated approach to achieving nominal DWPF glass production rates. The volumes of waste for each sludge batch are shown in Table 1.

\section{TABLF 1}

SIUDGE BATCBAS FOR THE DWPE

$\begin{array}{lll}\text { BATCH } & \text { TANKS } & \text { VOLUME_(galions) } \\ 1 & 15,18,21,22 & 644000 \\ 2 & 5,6,8,11,14,15,18,22 & 698000 \\ 3 & 4,7,12,21,47 & 709000 \\ 4 & 2,3,13,17,18,19,23,24,26,35 & 531000 \\ 5 & 1,9,10,26,32,39,43 & 536000 \\ 6 & 26,32-4,39,43 & 463000 \\ 7 & 26,33,34,39,43 & 155000 \\ \text { NPR } & -- & 120000 / \mathrm{yr}\end{array}$


The waste tanks from which each sludge batch is derived is also shown in Table 1.4 It has been assumed that Batches 6 and 7 contain significant quantities of recycled material from the DWPF. ${ }^{4}$

For purposes of the analysis in this report, it is assumed that after Batch 7, the DWPE is processing waste from the New Production Reactor (NPR). At this time, it is not possible to provide definitive estimates of the amount of waste which will be produced by processing NPR materials. Based on current waste generation oy H-Area, it is quite likely that the high-level. waste generated from actual reactor material processing will be only a small fraction of the waste which will eventually reach the DWPF. Thus, for this future waste, a waste generation rate of 10,000 gallons per month has been assumed, based on current waste receipts in the Tank Farm (For 1991, these have ranged from 4000 to 11000 gallons per month). This is also reflected in Table 1.

The factors (other than the volume) required to calculate the number of canisters on a mass basis have been derived from nominal Tank Farm values, and processing experience with vitrifying simulated sluages in pilot plant testing and actual sludges in $\mathrm{SRL}^{\prime} \mathrm{s}$ Shielded Cells Facility. They are:
Sludge solids per unit volume (lbs/gal):
$2.01 \pm 0.434$ for
existing waste, and
1.5 for NPR waste
(assumes dilute miscellaneous waste)
Mass of sludge oxides per unit mass of sludge: $0.713 \pm 0.0766$
Mass of sludge oxides in each canister: $0.28 \times 3710$ lbs of glass
per canister

The latter factor is assumed to be errorless, on the basis that deviations from the average should be normally distributed, and thus not affect the total number of canisters produced.

\section{ESTIMATED NUMBER OF CANISTERS}

The estimated number of canisters from each of the first seven sludge batches is shown in Table 2, calculated on both a mass and a volume basis. As can be seen, there is reasonably good agreement. On a mass basis, it is estimated that 5154 canisters will be produced from the first seven batches. On a volume basis, it is estimated that 5282 canisters will be produced. Thus, about 5200 will. be produced from the first seven sludge batches.

The values for NPR waste do not agree as well, primarily because the mass calculation uses a lower sludge solids to volume factor than for the first seven batches. This difference is not very significant, however, because of the uncertainties in future production generally (See section on Errors and Uncertainties).. 


\section{TABTE 2 \\ CANISTERS PRODUCED FROM EACH SIUDGE BATCH}

\section{BATCH}

2

4

5

6

7

NER

CANISTERS CALCULATED BX

MASS

888

963

978

733

739

639

214

124
VOLUJME

910

987

1002

751

758

655

219

170

\section{GBRORS ANR UNCERTAINTIES}

The estimated rumber of canisters from each sludge batch is subject to several sources of uncertainty, some quantifiable, and some less readily quantified. These include the uncertainty in current waste inventory, errors in the conversion factors used in the calculations above, and uncertainty in future waste generation. For purposes of these calculations, an assumed error of 1000 gallons in the volume of each sludge batch has been used. The errors in the conversion factors used in the mass calculations are shown above. If the numerical factors are treated as independent variables, then the standard deviation of the number of canisters can be approximated by

$$
\sqrt{\frac{(\overline{S C})^{2} \text { variance }(V)+(\overline{S V})^{2} \text { variance }(C)+(\overline{C V})^{2} \text { variance }(S)}{(0.28 * 3710)^{2}}}
$$

where $S=s l u d g e$ solids per gallon, $C=$ ratio of mass of oxides to mass of sludge, $V=s l u d g e$ volume in gallons, and the bar notation refers to the mean of the measured values.

Thus, the relative standard deviation in the calculated rumber of canisters is 61 of each of the estimates. The assumed lack of covariance is almost certainly not true. Unfortunately, there is insufficient information about the correlation among these factors to provide a bettex estimate of the error. 
Uncertainty in future waste generation is probably the major source of uncertainty in the estimated number of canisters, but cannot be easily quantified. Potential changes in the need for nuclear materials (e.g., due to heightened international tensions) or in the technologies deployed at SRS for production of nuclear materials could cause significant changes in waste generation at SRS. As an example, some flowsheets for processing the fuel from the New Production Reactor would give rise to extremely concentrated waste. Direct disposal of the irradiated materials is also being considered. Recycle of DWPF waste is assumed to become significant in batches 6 and 7 , but until the facility has been operated, any estimates of the amount of waste recycled to the Tank Farm are purely speculative.

\section{SIUDGE PROCESSING SCHEDUTE}

In order to derive a canister production schedule, it was assumed that the DWPF will begin glass production in December, 1993, at $50 \%$ of the design-basis rate (205 canisters per year). This rate would be maintained for the first year, then would increase to $75 \frac{\circ}{\circ}$ for the second year ( 307 canisters per year), and then increase again to the design-basis rate ( 410 canisters/year) starting in the third year (Note that these assumptions affect only the production schedule, not the estimated number of canisters). Starting with Batch 3, attalnment is assumed to decrease again, based on a lack of sufficiently cooled salt in the waste Tanks. These processing plans form the basis for the canister production schedule in Table 3.

\section{TABLE 3}

SLUDGE PROCESSING SCHEDUTE

\section{BATCH \\ DURATION $(E B O M$ - TOL}

1

2

3

4

5

6

7

NPR
$35(12 / 93-11 / 96)$

$28(12 / 96-3 / 99)$

$32(4 / 99-11 / 01)$

$26(12 / 01-1 / 04)$

$26(2 / 04-3 / 06)$

$37(4 / 06-4 / 09)$

$13(5 / 09-5 / 10)$

7 (beginning 6/10)
ASSUMED FRACTION OE DESIGN-BASIS RATE ( 8$)$

$50 / 75 / 100$

100

90

75

75

50

50

50 


\section{REFERENCES}

1. Office of Civilian Radioactive Waste Management, Waste Accoptance preliminary specifications for Vitrified Aigh-Level Waste Foxms, Draft for approval, June, 1991.

2. Defense Waste Processing Facility, DWPE Waste Form Compliance Plan, WSRC SW4-6, Revision 0, March, 1990.

3. A. S. Choi, J. R. Fowler, Matexial Balance Tables for the DWP Basic Data Report (DPSP-80-1033) Revision 138, WSRC-TR-90-93, February 28, 1990.

4. T. E. Pate, "Savannah River Site Radioactive Liquid Waste Forecast - 1990," WSRC-RP-90-589, June 29, 1990. 

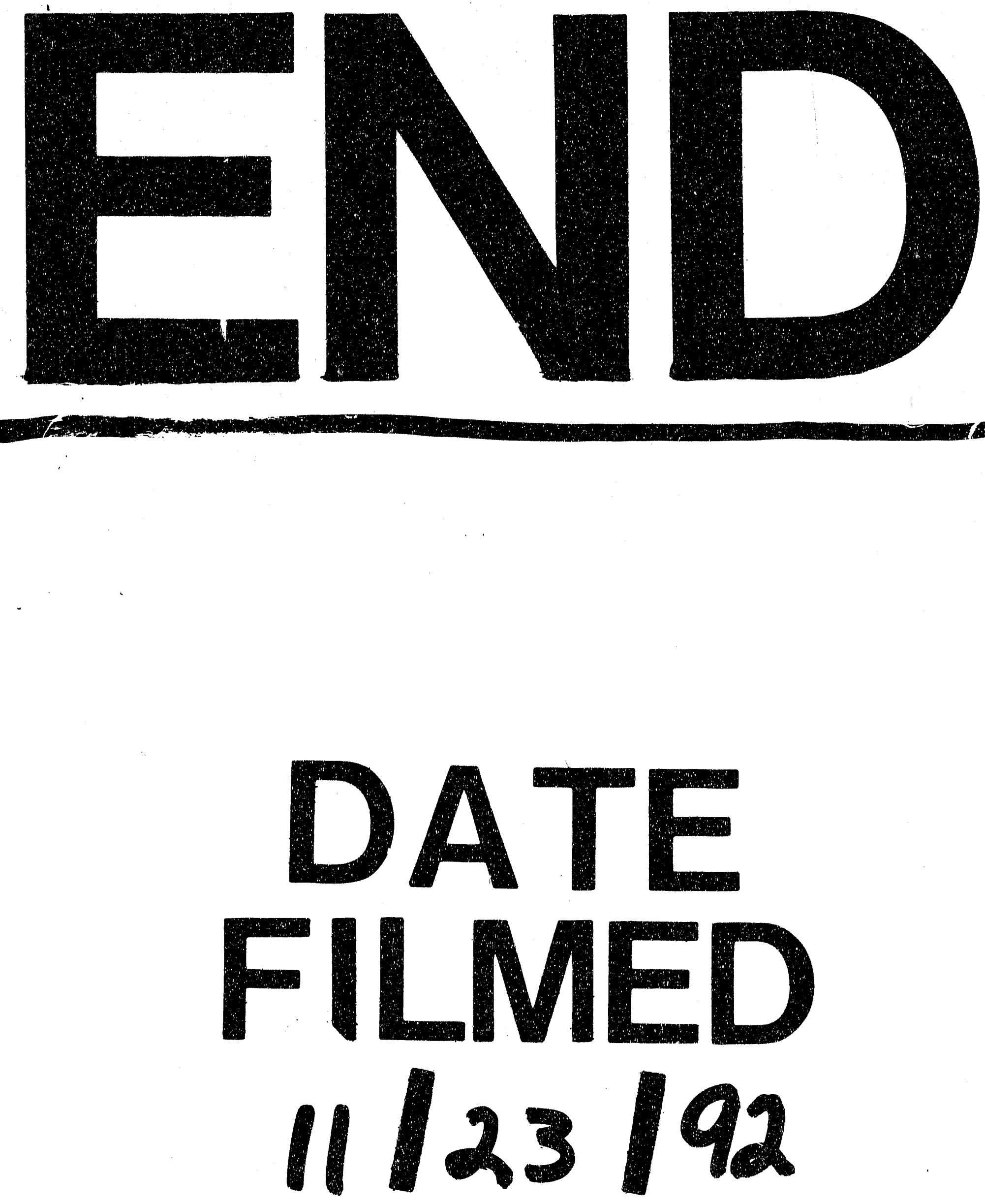


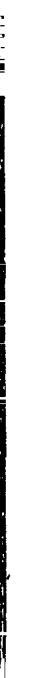

